\title{
LIMITATIONS ON CIVIL LIABILITY UNDER RULE 10b-5
}

\author{
David S. Ruder* \& NeIl S. Cross*
}

Securities and Exchange Commission rule 10b-5 has become well known as providing broad and important remedies for aggrieved investors. ${ }^{1}$ After avoiding rule $10 \mathrm{~b}-5$ for many years, the Supreme .Court has recently construed the rule in several decisions. ${ }^{2}$ The Court has recognized that an implied private right to enforce rule $10 \mathrm{~b}-5$ exists, stating in Superintendent of Insurance v. Bankers Life \& Casualty $\mathrm{Co}^{3}$ that "[i]t is now established that a private right of action is implied under Section 10(b)." The Court's general approval of rule

* Professor of Law, Northwestern University School of Law. B.A. 1951, Williams College; J.D. 1957, University of Wisconsin.

** Member, Class of 1973, Northwestern University School of Law.

1. The Sccurities Exchange Act of $1934 \S 10(\mathrm{~b}), 15$ U.S.C. $\S 78 \mathrm{j}$ (1970) [hereinafter cited as the 1934 Act] provides:

It shall be unlawful for any person, directly or indirectly, by the use of any means or instrumentality of interstate commerce or of the mails, or of any facility of any national securities exchange

...

(b) To use or employ, in connection with the purchase or sale of any security registered on a national securities exchange or any security not so registered, any manipulative or deceptive device or contrivance in contravention of such rules and regulations as the Commission may prescribe as necessary or appropriate in the public interest or for the protection of investors.

17 C.F.R. § $240.10 b-5$ (1972) [hereinafter cited as rule 10b-5] promuigated under section 10(b) provides:

It shall be unlawful for any person, directly or indirectly, by the use of any means or instrumentality of intcrstate commerce, or of the mails or of any facility of any national securities exchange,

(1) To employ any device, scheme, or artifice to defraud,

(2) To make any untrue statement of a material faet or to omit to state a material fact necessary in order to make the statements made, in the light of the circumstances under which they were made, not misleading, or

(3) To engage in any act, practice or course of business which operates or would operate as a fraud or deceit upon any person,

in connection with the purchase or sale of any security.

2. Affiliated Ute Citizens v. United States, 406 U.S. 128 (1972); Superintendent of Ins. v. Bankers Life \& Cas. Co., 404 U.S. 6 (1971). The first Supreme Court decision interpreting rule 10b-5 was SEC v. National Sec., Inc., 393 U.S. 453 (1969). The Court heard a prior case involving rule $10 \mathrm{~b}-5$ but did not interpret the rule. See Tcherepnin v. Knight, 389 U.S. 332 (1967).

3. 404 U.S. 6 (1971).

4. Id. at 13 n.9, citing VI L. Loss, Securities Regulation 3869-73 (1969); III Loss, supra, at 1763 et seq. (2d ed. 1961). For a discussion of the development of implied private 
10b-5 is apparent from the following statements interpreting the rule in Affiliated Ute Citizens v. United States: ${ }^{5}$

[T]he 1934 Act and its companion legislative enactments embrace a "fundamental purpose . . . to substitute a philosophy of full disclosire for the philosophy of caveat emptor and thus to achieve a high standard of business ethics in the securities industry." ${ }^{\circ}$. . . Congress intended securities legislation enacted for the purpose of avoiding frauds to be construed "not technically and restrictively, but flexibly to effectuate its remedial purposes."

This article identifies several areas in which the interpretation of facts can serve as a device for limiting liability under rule 10b-5 and advances theories for proper legal analysis of those areas. The areas discussed include materiality, reliance, causation, scienter and statutes of limitation-legal aspects of a rule $10 \mathrm{~b}-5$ cause of action which require factual findings to be made to. ${ }^{8}$ The article concludes that

right theories, see Comment, Private Remedies Under the Consumer Fraud Acts: The Judicial Approaches of Statutory Interpretation and Impiication, 67 Nw. U.L. REv. 413 (1972), and articles cited in Ruder, Current Developments in the Federal Law of Corporate Fiduciary Relations-Standing to Sue Under Rule lOb-5, 26 Bus. LAw, 1289, 1289-90 n.4 (1971).

5. 406 U.S. 128 (1972).

6. Id. at 151, quoting SEC v. Capital Gains Research Bureau, Inc., 375 U.S. 180, 186 (1963).

7. Id., quoting SEC v. Capital Gains Research Bureau, Inc., 375 U.S. at 195, and noting the subsequent approval of similar language in Superintendent of Ins. v. Bankers Life \& Cas. Co., 404 U.S. 6, 12 (1971).

8. Although the general analysis in this article will not be specifically directed to aspects of the securities laws other than rule 10b-5, some of the discussion will be applicable to the development of remedies in other acts. For instance, the Investment Company Act of 1940, 15 U.S.C. $\$ 80 \mathrm{a}-1$ to $-52(1970)$, has been interpreted in many recent decisions to permit private actions to enforce fiduciary obligations. See, e.g., Rosenfeld v. Black, 445 F.2d 1337 (2d Cir. 1971); Moses v. Burgin, 316 F. Supp. 31 (D. Mass. 1970), affd in part and modified, 445 F.2d 369 (1st Cir.), cert. denied, 404 U.S. 994 (1971); Brown v. Bullock, 194 F. Supp. 207 (S.D.N.Y.), affd on other grounds, 294 F.2d 415 (2d Cir. 1961). Brouk v. Managed Funds, Inc., 286 F.2d 901 (8th Cir.), cert. granted, 366 U.S. 958 (1961), vacated as moot upon settlement, 369 U.S. 424 (1962), apparently reached an opposite result, but the Eighth Circuit has indicated its desire to disavow Brouk. See Greater Iowa Corp. v. McLendon, 378 F.2d 783 (8th Cir. 1967). See generally Note, Private Rights of Action Against Mutuai Fund Investntcut Advisers: Amended Section 36 of the 1940 Act, 120 U. PA. L. REv. 143 (1971). Margin regulations are also privately enforceable. See, e.g., Pearlstein v. Scudder and German, 429 F.2d 1136 (2d Cir. 1970), rev'g and remanding, 295 F. Supp. 1197 (S.D.N.Y. 1968); Scrzysko v. Chase Manhattan Bank, 290 F. Supp. 74 (S.D.N.Y. 1968), aff'd, 409 F.2d 1360 (2d Cir.), cert. denied, 396 U.S. 904 (1969). The trend appears to be toward permitting private enforcement of stock exchange rules and the rules of the National Association of Securities Dealers. For an early leading case discussing the problem of private enforcement of such rules, sce Colonial Realty Corp. v. Bache \& Co., 358 F.2d 178 (2d Cir.), cert. denied, 385 U.S. 817 (1966). For cases in the Seventh Circuit indicating the trend toward private cnforcement, sce SEC v. First Sec. Co., 466 F.2d 1035 (7th Cir. 1972) (holding that NASD rule 27 is privately enforceable), reprinted in 1972 CCH FED. SEC. L. REP. I 93,430; Avern Trust v. Clarke, 415 

$1942 .{ }^{13}$ Its first reported use by the SEC came in a 1943 case, In re Ward La France Truck Corp. ${ }^{14}$

Although the 1934 Act does not provide an express right to private parties to enforce rule 10b-5, the Supreme Court's Bankers Life statement ${ }^{15}$ and its grant of a private remedy in the Affiliated Ute Citizens litigation ${ }^{16}$ seem to have settled the private remedy question. ${ }^{17}$ These cases stem from J.I. Case v. Borak, ${ }^{18}$ which held that an implied private right of action exists for violation of the federal proxy rules ${ }^{19}$ on the theory that the phrase "the protection of investors" implies the availability of a private right of action "where necessary to achieve that result." ${ }^{20}$ The broad approach taken by the Court in Borak toward development of implied remedies has assisted

13. SEC Securities Exchange Act Release No. 3230 (May 21, 1942).

14. 13 S.E.C. 373 (1943).

15. See note 4 supra and accompanying text.

16. 406 U.S. 128 (1972).

17. Arguably, the Bankers Life case and the Affiliated Ute Citizens case could be distinguished on their facts; thus, to some extent the private rights question can be considered to be unsettled. Bankers Life involved alleged fraud in connection with the disposition of procceds from the sale of corporate securities. Affiliated Ute Citizens involved sale of securities by the plaintiffs to and through bank employees owing fiduciary obligations to the plaintiffs. Since both of these cases involved activities for which no express private remedy is provided in either the 1933 or 1934 Acts, opportunity may still exist for a defendant to argue in the Supreme Court that a remedy should not be implied in circumstances in which an express private remedy also exists. However, it is noteworthy that circuit courts have not accepted arguments that no remedy should be implied when a private remedy exists under seetions 11 and 12(2) of the 1933 Act, 15 U.S.C. $\$ 77 \mathrm{k}, l(2)$ (1970), or seetions 9 and 18 of the 1934 Act, id. $\$ 78 \mathrm{i}$, r. See Jordan Build. Corp. v. Doyle, O'Connor \& Co., 401 F.2d 47 (7th Cir. 1968) (rejecting a contention that the statute of limitations contained in section 29(b), 15 U.S.C. $\S 78 \mathrm{cc}(1970)$, governs an action against brokers and stating that remedies under the securities acts are "cumulative"); Ellis v. Carter, 291 F.2d 270 (9th Cir. 1961) (holding that despite similar provisions in section 12(2) of the 1933 Act, a buyer's remedy will be provided under rule 10b-5); Fischman v. Raytheon Mfg. Co., 188 F.2d 783 (2d Cir. 1951) (holding that a rule 10b-5 action will exist where an element of fraud is added to the requirements needed for violation of section 11 of the $1933 \mathrm{Act}$ ).

Some support for an opposite result may be reached by an examination of cases such as Schaefer v. First Nat'1 Bank, 326 F. Supp. 1186 (N.D. III. 1970), order granting appeal rev'd, 465 F.2d 234 (7th Cir. 1972), in which the district court found an argument that section 9(e) provides the exclusive remedy for market manipulation "logically persuasive," $i d$. at 1189, but rejectcd defendant's argument in reliance upon the authority of Jordan and Gilbert v. Nixon, 429 F.2d 348 (10th Cir. 1970). In the Gilbert decision, the Tenth Circuit had admitted that an action under rule 10b-5 could exist despite a remedy under section 12(2) of the 1933 Act but had resolved conflicts between the two remedies by reading the limitations of section 12(2) into the rule $10 \mathrm{~b}-5$ remedy.

18. 377 U.S. 426 (1964).

19. Id. at 432.

20. Id. 
in the development of rule 10b-5 on an ad hoc basis in an extremely "flexible" fashion. ${ }^{21}$

\section{Coverage of THe Rule}

The language of rule $10 \mathrm{~b}-5$ is extremely broad. The rule makes it unlawful for "any person directly or indirectly" to engage in certain prohibited activities "in connection with the purchase or sale of any security." ${ }^{22}$ As the interpretation of the rule has devcloped, the number and variety of prohibited activities have increased. The proscribed activities include misrepresentations ${ }^{23}$ and half-truths, ${ }^{24}$ which are forbidden by subsection two of the rule. More important, howcver, subsections one and three prohibit employment of "any device, scheme or artifice to defraud" 25 or use of "any act, practice or course of business which operates or would operate as a fraud or deceit." 26 This languagc has been interprcted to prohibit nondisclosure in circumstances in which a duty to disclose is said to exist. ${ }^{27}$ It has also been intcrpreted to prohibit nonverbal acts, such as the failure to declare a dividend ${ }^{28}$ or mismanagement of a corporation, ${ }^{29}$ where the purpose is to drive down the price of shares so that insidcrs can benefit by purchasing at low prices. ${ }^{30}$

21. See generally Friendly, In Praise of Erie-And of the New Federal Common Law, 39 N.Y.U.L. Rev. 383, 413-14 (1964); Ruder, Texas Gulf Sulphur-The Second Round: Privity and State of Mind in Rule 10b-5 Purchase and Sale Cases, 63 Nw. U.L. REv. 423, 430-33 (1968). The most vigorous champion of rule $10 \mathrm{~b}-5$ has been the General Counsel's Office of the Securities and Exchange Commission, which has been active in the development of rule 10b5 doctrine on a case-by-case basis since its early participation as amicus curiae in Kardon v. National Gypsum Co., 69 F. Supp. 512 (E.D. Pa. 1946) (motion to dismiss), 73 F. Supp. 798 (E.D. Pa. 1947) (on merits), 83 F. Supp. 613 (E.D. Pa. 1948) (findings of fact and law). The Kardon case was the first case holding that an implied private right of action exists to enforce rule 10b-5.

22. 17 C.F.R. $\S 240.10 b-5$ (1972).

23. Id. $\$ 240.10 \mathrm{~b}-5(2)$.

24. Id.

25. 1 d. $\$ 240.10 b-5(1)$.

26. Id. $\S 240.10 \mathrm{~b}-5(3)$.

27. E.g., SEC v. Texas Gulf Sulphur Co., 258 F. Supp. 262 (S.D.N.Y. 1966), aff $d$ in part and rev'd in part, 40I F.2d 833 (2d Cir. 1968), cert. denied, 394 U.S. 976 (1969), on remand, 312 F. Supp. 77 (S.D.N.Y. 1970), affd in part and rev'd in part, 446 F.2d 1301 (2d Cir.), cert. denied, 404 U.S. 1005 (1971), decision on remand, 331 F. Supp. 671 (S.D.N.Y. 1971).

28. Cochran v. Channing Corp., 211 F. Supp. 239 (S.D.N.Y. 1962).

29. Mutual Shares Corp. v. Genesco, Inc., 384 F.2d 540 (2d Cir. 1967).

30. In cases which have clearly involved reprehensible conduct, the federal courts have applied rule 10b-5 directly to assess damages against broker-dealers. For instance, in Hecht v. Harris, Upham \& Co., 430 F.2d 1202 (9th Cir. 1970), modifying and aff g, 283 F. Supp. 417 (N.D. Cal. 1968), the Ninth Circuit affirmed tbe imposition of monetary damages upon the 


\section{Purchase and Sale Cases}

Rule 10b-5 is best known in cases involving purchases or sales of securities, the so-called trading cases, and the discussion in this article is directed primarily to those cases. In trading cases the rule has been applied to direct transactions between individuals since the early case of Fratt v. Robinson. ${ }^{31}$ It has also been applied to market transactions..$^{32}$ In either direct or market transactions it is unlawful for any person to make a misrepresentation in connection with the purchase or sale of a security. Misrepresentation doctrines are applied equally to all defendants, without regard to the relationship between the plaintiff and the defendant. All persons may be said to be under a duty to speak truthfully. ${ }^{33}$

On the other hand, when a securities transaction occurs without disclosure of non-public material corporatc information, liability will depend upon the identity of the offending party. At present, obligations to disclose when purchasing or selling securities exist for offcers, directors, and majority shareholders, ${ }^{34}$ as well as for other persons who are in a special relationship to a company and privy to its internal affairs so that they receive access to information intended to be available only for a corporate purpose. ${ }^{35}$ These obligations are also imposed upon "tippees" who trade without disclosure..$^{36}$

In addition to identifying the duty which every person owes not to make misrepresentations and the duty whieh an insider or "tippee"

\footnotetext{
New York partners of a broker-dealer who had failed to supervise a registered representative properly. 430 F.2d at 1209-10. The representative had churned a customer's account. Regarding broker-dealer obligations generally, see cases cited in Hecht, id. at 1207. For discussion of churning, see Comment, Churning by Securities Dealers, 80 HaRv. L. Rev. 869 (1967); Note, Churning: A Critical Analysis, 14 N.Y.L.F. 315 (1968). In Chasins v. Smith, Barney \& Co., 438 F.2d 1167 (2d Cir. 1970), the Second Circuit imposed liability upon a brokerage firm which failed to reveal to its customer that it was a market maker in the security which it sold to that customer. On the other hand, customers' activities have also been subject to rule 10b-5 remedies. In A.T. Brod \& Co. v. Perlow, 375 F.2d 393 (2d Cir. 1967), the Second Circuit reversed the district court's dismissal of a complaint in a broker-dealer's suit against a customer who allegedly had ordered securities but intended to pay only if the market value increased. The court stated that "novel or atypical methods should not provide immunity from the securities laws." Id. at 397.

31. 203 F.2d 627 (9th Cir. 1953).

32. See, e.g., Speed v. Transamerica Corp., 99 F. Supp. 808 (D. Del. 1951), affd as modified, 235 F.2d 369 (3d Cir. 1956). (1971).

33. Mitchell v. Texas Gulf Sulphur Co., 446 F.2d 90 (10th Cir.), cert. denied, 404 U.S. 1004

34. Speed v. Transamerica Co., 99 F. Supp. 808 (D. Del. 195I), aff'd as modified, 235 F.2d 369 (3d Cir. 1956); Kardon v. National Gypsum Co., 83 F. Supp. 613 (E.D. Pa. 1947).

35. In re Cady, Roberts \& Co., 40 S.E.C. 907,912 (1961).

36. See In re Investors Management Co., CCH FED. SEC. L. ReP. Tा 78,163 (SEC 1971).
} 
owes to make full disclosure when purchasing or selling stock, it is important to identity those individuals to whom the duty is owed. Where parties are dealing with each other in face-to-face transactions, it is relatively easy to apply the misrepresentation and nondisclosure doctrines. However, where misrepresentations reach large groups of purchasers or sellers, or where an insider trades in an impersonal market in which many other persons are also trading, the extent of liability will depend in part upon whether a contractual connection, sometimes referred to as "privity," is required between the wrongdoer and the injured party. In this regard the federal courts have in general moved from a relatively restrictive interpretation ${ }^{37}$ to the liberal conclusion that no privity requirement exists. ${ }^{38}$

Elimination of the doctrine of privity coupled with the growth of class actions under Federal Rule of Civil Procedure 23 has raised difficult issues in market cases which do not exist in cases involving direct transactions, since in market cases it is possible for a court to impose damages in substantial amounts. For instance, in Mitchell $v$. Texas Gulf Sulphur Co ${ }^{39}$ recovery was granted to three plaintiffs against a corporation which had not engaged in a trading transaction but which had issued a misleading press release characterized by the court as intentional and deliberate. ${ }^{40}$ Although the Mitchell case did not involve a class action, its principles are transferable to the class action setting. The case involved a misrepresentation, deliberate conduct, and an absence of a direct transaction between the plaintiffs and the defendant. The theory apparently underlying willingness to impose large liability in misrepresentation market cases of the Mitchell type is that a wrongdoer acting deliberately or recklessly should be responsible for all of the injuries inflicted by that conduct. ${ }^{41}$

Where the reprehensible market conduct is nondisclosure coupled

37. See Joseph v. Farnsworth Radio \& Television Corp., 99 F. Supp. 701,706 (S.D.N.Y. 1951), affd, 198 F.2d 883 (2d Cir. 1952).

38. See, e.g., Reynolds v. Texas Gulf Sulphur Co., 309 F. Supp. 548 (D. Utah 1970), affd in part and rev'd in part, sub nom., Mitchell v. Texas Gulf Sulphur Co., 446 F.2d 90 (10th Cir. 1971), cert. denied, 405 U.S. 918 (1972). See generally Ruder, Texas Gulf Sulphur-The Second Round, supra note 21; Ruder, Multiple Defendanis in Securities Law Fraud Cases. Aiding and Abetting, Conspiracy, In Pari Delicto, Indemnification, and Contribution, $120 \mathrm{U}$. PA. L. Rev. 597, 618-20 (1972).

39. 446 F.2d 90 (10th Cir. 1971).

40. Id. at $97-98$.

41. Whether such liability should be imposed for negligent conduct is an unsettled and difficult question. See discussion infra notes 83-94 and accompanying text. See also Ruder, Multiple Defendants, supra note 38, at 612-18. 
with trading, different policy considerations exist. If liability is limited to those persons who can trace their transactions to the insider, the plaintiffs who recover will be receiving a windfall due to the accident that their transactions could be traced to insiders. Additionally, the deterrent value of such a policy will be small, since at most the defendant will merely lose his profit. Conversely, if a defendant is required to pay full damages to all persons who traded during the period of his trading, the defendant may be financially destroyed. Even if the conduct is deliberate, it is difficult to see how the defendant's act of trading injures anyone other than the person with whom he deals. Financial destruction in such circumstances seems harsh if not cruel.

\section{The Potential Impact of Factual Determinations on Outcome}

This article does not purport to suggest solutions to the policy dilemmas created by abolition of the privity requirement. The problems have been identified in order to place the role of courts and juries in proper perspective. As rule $10 \mathrm{~b}-5$ has developed, the possibility of large damages has given the trier of fact, whether it be court or jury, enormous responsibility to reach fair decisions. Since rule $10 \mathrm{~b}-5$ is developing on an ad hoc basis, it is appropriate to emphasize the role which the various elements contained in the rule can play in influencing results. Proper application of these elements can achieve the flexibility inherent in making determinations based upon considerations of fairness. In the discussion which follows, it is suggested that flexible results in rule 10b-5 cases can be maintained through interpretation of the elements of materiality, reliance, causation and scienter and through interpretation of statutes of limitation. ${ }^{42}$

\section{The Definition of "Material Fact"}

One of the first questions reached by the trier of fact in deciding a rule $10 \mathrm{~b}-5$ trading case will be whether the misrepresented or nondisclosed fact was material. Resolution of that question provides an initial opportunity to affect liability. In resolving the materiality question the trier of fact will be applying an objective or reasonable man test. That test has been most clearly stated in List v. Fashion Park, Inc. ${ }^{43}$ in which the court stated that the basic test is whether

42. Other available areas of flexibility, such as burden of proof considerations and damages, will not be discussed.

43. 340 F.2d 457 (2d Cir.), cert. denied, 382 U.S. 811 (1965). 
a reasonable man would attach importance to the misrepresented or nondisclosed information in determining his choice of action in the transaction in question. ${ }^{44}$

In SEC v. Texas Gulf Sulphur Co. ${ }^{45}$ the district court stated that material information is

information which in reasonable and objective contemplation might affect the value of the corporation's stock or securities. . . . It is information which, if known, would clearly affect "investment judgment" . . . or which directly bears on the intrinsic value of a company's stock..$^{48}$

The Tenth Circuit in Mitchell v. Texas Gulf Sulphur Co. ${ }^{47}$ recently stated the following:

Misrepresented or omitted facts become material, hence actionable under $10 \mathrm{~b}$ 5 when, considering the complaining parties as reasonable investors, the disclosure of the undisclosed facts or candid revelation of misleading facts would affect their trading judgment. . . . The implicit variables to be weighed in a materiality analysis are the magnitude and probability of the occurrence of the event, set against the size and total activity of the subject company. ${ }^{48}$

The flexibility available to a trier of fact in applying the Tenth Circuit's definition is obvious. This flexibility may have been expanded further by the Supreme Court's recent use of the word "might" in referring to the materiality definition. In the Affiliated Ute Citizens case the Court stated: "All that is necessary is that the facts withheld be material in the sense that a reasonable investor might have considered them important in the making of this decision." ${ }^{40}$

No matter what the announced definitions of materiality and material fact are, the manner in which the standards are applied will probably be the most important factor in determining liability. In $S E C$ v. Texas Gulf Sulphur Co. the district court found that knowledge as of November 12, 1963, relating to a valuable mineral discovery, was not material until April 9, 1964, a date after which additional

44. Id. at 462 , quoting RESTATEMENT OF TORTS $\$ 538(2)$ (1938). This test has been reaffirmed by the Second Circuit. See Radiation Dynamics Inc. v. Goldmutz, 464 F.2d 876 (2d Cir. 1972); Chasins v. Smith, Barney \& Co., 438 F.2d 1167 (2d Cir. 1970); SEC v. Texas Gulf Sulphur Co., 401 F.2d 833, 849 (2d Cir. 1968), aff'g 258 F. Supp. 262 (S.D.N.Y. 1966), cert. denied, 394 U.S. 976 (1968).

45. 258 F. Supp. 262 (S.D.N.Y. 1966).

46. Id. at 280 (citations omitted).

47. 446 F.2d 90 (10th Cir. 1971).

48. Id. at 97 (citations omitted).

49. 406 U.S. at 153-54 (emphasis added). 
drilling results were known. ${ }^{50}$ On the other hand, the court of appeals held that the drilling results were material on the earlier date..$^{51}$ As a result of the court of appeals' opinion additional defendants were found to have violated rule $10 \mathrm{~b}-5.52$ The two opinions seem to reflect different views regarding the equities of the case rather than differ.ences regarding definition. ${ }^{53}$ The court of appeals clearly indicated its willingness to treat the materiality requirement flexibly by the following statement:

In each case, then, whether facts are material within Rule 10b-5 when the facts relate to a particular event and are undisclosed by those persons who are knowledgeable thereof will depend at any given time upon a balancing of both the indicated probability that the event will occur and the anticipated magnitude of the event in light of the totality of the company activity.4

\section{The Reliance Requirement}

Closely related to the concept of materiality is the requirement of "reliance." To the extent that a reliance requirement exists, the trier of fact must determine whether the plaintiff relied upon the misrepresentation or nondisclosure. In making its determination, the trier of fact will be applying a subjective test to the facts at hand. The Second Circuit set forth the following definition of the reliance requirement in List v. Fashion Park, Inc..$^{55}$

[T] he test of "reliance" is whether "the misrepresentation is a substantial factor in determining the course of conduct whieh results in [the recipient's] loss." 58

Although the concept of reliance is difficult to apply in a nondisclosure case, the Second Circuit did so in List, characterizing the test as "whether the plaintiff would have been influenced to act differently than he did act if the defendant had disclosed to him the undisclosed fact." $" 57$

In common vernacular the reliance requirement means that no

50. 258 F. Supp. at 282.

51. 40 I F.2d 833, 852 (2d Cir. 1968).

52. Id. at $851-56$.

53. The Second Circuit attempted to meet this point by stating that the district court had chosen a standard which was too "conservative." Id. at 849. Despite this explanation, it seems clear that the different holding in the court of appeals resulted because the appellate judges found the defendants' conduct more reprehensible than did the lower court judge.

54. Id. at 849 .

55. 340 F.2d 457 (2d Cir.), cert. denied, 382 U.S. 811 (1965).

56. 340 F.2d at 462, quoting RESTATEMENT OF TORTS $§ 546$ (1938).

57. Id. at 463. 
rule $10 \mathrm{~b}-5$ recovery will be permitted where the plaintiff did not care whether or not the facts represented to him were true or would not have acted differently had the true facts been revealed to him, even though a reasonable investor might have been influenced by knowledge of the true facts. For instance, in the List case the court held that it need not consider whether the identity of the buyer of securities was a material fact to the plaintiff List because List had such confidence in his own financial wisdom that the identity of the buyer was of little or no concern to him..$^{58}$

Retention of a reliance requirement in rule $10 \mathrm{~b}-5$ cases involving direct face-to-face transactions is a useful way of preserving options for the trier of fact. For instance, the judge or jury may decide the case in the defendant's favor by determining that the plaintiff did not care about the facts represented or would not have been influenced by the facts omitted. However, application of the reliance requirement in class actions resulting from market transactions is much more difficult. In a class action setting, the problem is that the "kinds or degrees of reliance" may be so diverse that the litigation is no longer suitable for treatment as a class action. ${ }^{59}$ While such a contention may be met by a holding that the nature of the misrepresentation or nondisclosure is such that a common core of reliance probably exists, proof of reliance nevertheless must be presented on an individual basis at some point in the litigation. ${ }^{60}$ Individual trials on the reliance point, if required, may prove either too costly or too burdensome to be justified. Pressures thus exist either to eliminate the reliance requirement or to declare that an action requiring proof of

58. Id. at 464. See also Kohler v. Kohler Co., 319 F.2d 634, 641-42 (7th Cir. 1963).

59. The Advisory Committee for the Federal Rules of Civil Procedure has stated the problem as follows:

The court is required to find, as a condition of holding that a class action may be maintained under this subdivision, that the questions common to the class predominate over the questions affecting individual members. It is only where this predominance exists that economies can be achieved by means of the class-action device. In this view, a fraud perpetrated on numerous persons by the use of similar misrepresentations may be an appealing situation for a class action, and it may remain so despite the need, if liability is found, for separate determination of the damages suffered by individuals within the elass. On the other hand, although having some common core, a fraud case may be unsuited for treatment as a class action if there was material variation in the representations made or in the kinds or degrees of reliance by the persons to whom they were addressed. Proposed Amendments to Rules of Civil Procedure, 39 F.R.D. 69, 103 (1966).

See generally Note, The Impact of Class Actions on Rule 10b-5, 38 U. CHI. L. Rev. 337, 34245 (1971).

60 . Some courts have avoided considering the question whether proof of reliance by individ- 
individual reliance is not a proper subject for a class action.

In lieu of accepting either of the last two more drastic suggestions, a solution more consistent with concepts of fairness would be to treat reliance as presumed in class action cases, subject to rebuttal where appropriate. The presumption approach is consistent with results in recent class action cases, although the word "presumption" has not been used. For instance, the List court interpreted Speed $v$. Transamerica Corp ${ }^{61}$ as permitting a class action because "the court was convinced that all members of the class had relied on defendant's misrepresentation." ${ }^{62}$ A similar result was reached in Mader $v$. Armel, ${ }^{63}$ in which the Sixth Circuit stated: "[I]f reliance is a prerequisite to the rule, it is "little more than a formal requirement." "04

In nondisclosure cases involving many persons, the presumption approach seems particularly useful. In these cases a presumption of reliance is logical, since the class is assumed to be composed of reasonable investors. If an undisclosed fact would be material to a reasonable investor, a class composed of such investors presumptively would have relied upon that fact. This rationale was directly applied in Mills v. Electric Auto-Lite Co. ${ }^{65}$ in which the Supreme Court held that in a proxy case reliance was satisfied by a showing of materiality. The Court stated:

Where there has been a finding of materiality, a shareholder has made a

ual class members is necessary by suggesting the split trial device. See Korn v. Franchard Corp., [1971-1972 Transfer Binder] CCH FED. SEC. L. REP. If 93,397, at 91,997-98 (2d Cir. 1972); Green v. Wolf Corp., 406 F.2d 291, 301 (2d Cir. 1968); Wolfson v. Solomon, [1971-1972 Transfer Binder] CCH Fed. Sec. L. REP. ๆ 93,343, at 91,842, 91,847 (S.D.N.Y. 1972) (liability and damages may need to be tried separately, or even by different juries). In Korn the court, after noting that "[i]n fraud or $10 \mathrm{~b}-5$ cases . . . various rules, mechanisms, or presump. tions have been put forward for mitigating the problem of showing reliance . . .," cited with approval the following approaches:

Split trials for individual proof of reliance . . . ; inferring from the materiality of the misstatement that a reasonable investor would have relied; stressing general reliance on a common course of conduct over a period of time, dispensing with or minimizing the need to prove individual reliance in cases of nondisclosure; using the test, in instances of omission, of whether the claimant would have been influenced to act differently, if the undisclosed fact had been made known, than he in fact did. Id. at 91,997-98 (citations omitted).

61. 99 F. Supp. 808 (D. Del. 1951).

62. 340 F.2d at 463 .

63. 402 F.2d 158 (6th Cir. 1968).

64. Id. at 163, citing Myzel v. Fields, 386 F.2d 718 (8th Cir. 1967), cert. denied, 390 U.S.

951 (1968), and quoting 111 Loss, supra note 4, at 735 (2d ed. 1961).

65. 396 U.S. 375 (1970). 
sufficient showing of causal relationship between the violation and the injury for which he seeks redress if, as here, he proves that the proxy solicitation itself, rather than the particular defect in the solicitation materials, was an essential link in the accomplishment of the transaction. ${ }^{66}$

After agreeing with the court of appeals that "[r]eliance by thousands of individuals, as here, can scarcely be inquired into," ${ }^{\prime 67}$ the Court found that the plaintiffs had established their case by showing that the proxies necessary for corporate action had been obtained through a "materially misleading solicitation." 68

If a presumption of reliance is appropriate in a nondisclosure case brought as a class action, it should also be appropriate in a class action misrepresentation case. If a material misrepresentation reaches a class, the members of that class, if assumed to be reasonable, can be presumed to have relied upon that misrepresentation. Recently, in Kohn v. American Metal Climax, Inc., ${ }^{69}$ the Third Circuit reached this conclusion in a rule $10 \mathrm{~b}-5$ misrepresentation case, stating:

We think those alleging a violation of Rule $10 \mathrm{~b}-5$ have an obligation to show a fraudulent and material misrepresentation and that, to the extent a reliance factor is required, in the present context it is encompassed by the finding that the misrepresentation was material..$^{70}$

Other factors may justify the reliance presumption. The Supreme Court in the Affiliated Ute Citizens case ${ }^{71}$ apparently concluded that proof of reliance is not required in nondisclosure cases in which a special relation of trust and confidence exists. In that case, employees of a bank charged with the responsibility of advising mixed-blood Indians regarding transactions in securities utilized their position of trust and confidence to induce the Indians to sell their securities to themselves and their friends and did not disclose the true value of the shares. ${ }^{72}$ The Court stated:

Under the circumstances of this case, involving primarily a failure to disclose,

66. Id. at 385 .

67. Id. at 380 .

68. Id. at 386.

69. 458 F.2d 255 (3d Cir. 1972).

70. Id. at 269 , referring to a rule $10 \mathrm{~b}-5$ case based upon a proxy violation, Crane Co. v. Westinghouse Air Brake Co., 419 F.2d 787 (2d Cir. 1969), cert. denied, 400 U.S. 822 (1970).

71. 406 U.S. 128 (1972).

72. Additionally, the defendants had a duty of disclosure because of their position as market markers in the stock. Id. at 153. The court reasoned by analogy from a case involving non-disclosure by a brokerage firm engaged in market-making activities, Chasins v. Smith, Barney \& Co., 438 F.2d 1167 (2d Cir. 1970). 
positive proof of reliance is not a prerequisite to recovery. All that is necessary is that the facts withheld be material in the sense that a reasonable investor might have considered them important in the making of this decision. ${ }^{73}$

The Supreme Court's apparent elimination of the reliance requirement can be reconciled with a presumption theory, since the Court first found the existence of a relationship upon which the plaintiffs could be presumed to have relied.

Despite the pressures toward elimination of reliance in class action cases, retention of the requirement seems desirable as a method of permitting courts to arrive at just results. In litigation resulting from a face-to-face transaction, the defendant should not be denied the opportunity to present proof that the plaintiff did not rely upon his misrepresentation or omission. In the class action setting, even though reliance may be presumed, the defendant should similarly have the opportunity to present proof that the presumption of reliance is incorrect. In class action litigation such proof might merely amount to further argument regarding materiality, but it could center around other factors, such as the question of whether corrective material reached the class. ${ }^{74}$ If such a presumption were accepted as to the class, that broad presumption should not foreclose proof that a particular member of the class did not rely. Since the practical result of the presumption technique as thus applied would be to shift the burden of going forward, it seems likely that proof regarding a particular member of the class would be forthcoming only when the amount at issue with regard to that member justified the expense of the defense.

\section{CAUSATION}

The reliance and materiality requirements sometimes are intertwined with the concept of causation. For instance, in List v. Fashion Park, Inc. ${ }^{75}$ the court refused to abandon the reliance requirement because it was unwilling to be regarded as "reading out of the rule so basic an element of tort law as the principle of causation in fact."76

Properly treated, the concept of causation should be.divided into two aspects-causation in fact and legal cause. ${ }^{77}$ The factual cause

73. 406 U.S. at $153-54$.

74. See Mitchell v. Texas Gulf Sulphur Co., 446 F.2d 90, 102-03 (10th Cir.), cert. denied, 404 U.S. 1004 (197I); Reynolds v. Texas Gulf Sulphur Co., 309 F. Supp. 548, 559-62 (D. Utah 1970). aff'd in part and rev'd in part sub. nom., Mitchell v. Texas Gulf Sulphur Co., 446 F.2d 90 (10th Cir. 1971), cert. denied, 405 U.S. 918 (1972).

75. 340 F.2d 457 (2d Cir. 1964), cert. denied, 382 U.S. 811 (1965).

76. Id. at 463.

77. The influence of tort law on rule $10 \mathrm{~b}-5$ continues. For provocative discussions of cause 
element should require a showing that defendant's activities alleged to have violated rule $10 \mathrm{~b}-5$ were a "substantial factor" in plaintiff's injury. Determination of this factual question gives the trier of fact another means of reaching an equitable result. On the other hand, once the plaintiff has shown causation in fact, the defendant might still avoid liability by showing that his action was not a "legal" cause of plaintiff's injury. Legal cause questions require analysis of duty and other policy elements, which provides a court with further opportunity to influence outcome.

Causation principles were applied in Reynolds $v$. Texas Gulf Sulphur $\mathrm{Co}^{78}$ In holding that plaintiff Karlson could not recover from Texas Gulf Sulphur for the company's misleading press release because it was issued after his sale, the court implicitly determined that no factual cause existed between Karlson's sale in December of 1963 and the company's misleading statement in April of $1964 .{ }^{79}$ However, with regard to defendant Fogarty, who purchased Texas Gulf Sulphur shares without disclosing inside information known to him, a finding of factual cause would have been possible. Fogarty's purchases took place both before and after Karlson's sale, and had Fogarty disclosed inside information known to him, Karlson arguably would not have sold. In finding that Fogarty was not liable to Karlson, ${ }^{80}$ the court relied upon legal cause or duty language, stating that Fogarty did not owe a duty to disclose during the period in which there were good reasons for the company to keep the information secret. ${ }^{81}$

To the extent that the inquiry regarding causation centers on cause in the factual sense, the trier of fact will be given another area in which to exercise judgment in determining whether liability should be imposed. The "substantial factor" test, which requires that the defendant's conduct be a substantial factor in bringing about harm to the plaintiff, provides an opportunity for considerations of fairness to be brought into play. ${ }^{82}$ Even when it can be shown that the harm would not have occurred had the alleged wrongdoer's activities not

problems, see Green, Duties, Risks, Causation Doctrines, 41 Tex. L. Rev. 42 (1962); Green, The Causal Relation Issue In Negligence Law, 60 MiCH. L. Rev. 543 (1962).

78. 309 F. Supp. 548 (D. Utah 1970), aff'd in part and rev'd in part sub nom., Mitchell v. Texas Gulf Sulphur Co., 446 F.2d 90 (10th Cir. 1971), cert. denied, 405 U.S. 918 (1972).

79. Id. at 559.

80. Id. The district court also stated that privity of contract is not required in a rule $10 \mathrm{~b}-5$ action. Id. at 558. See notes 37-38 supra and accompanying text.

81. 309 F. Supp. at 558-59.

82. See generally Restatement (SECOND) OF TORTS $\$ \$ 435-39$ (1965) (dealing with the causal relation necessary for responsibility for negligence). Use of causation concepts does not promise clarity or predictability, since the role of causation in legal theory generally is far from clear. 
taken place, the trier of fact should be allowed to decide that the activities were not substantial enough in relation to plaintiff's harm to justify the imposition of liability.

\section{THE SCIENTER OR INTENT REQUIREMENT}

Three elements of rule $10 \mathrm{~b}-5$ purchase and sale actions which can be considered by the trier of fact in order to determine outcome have been discussed-materiality, reliance and causation. Interpretation of doctrines of scienter or intent may be equally important. However, despite numerous cases and much comment dealing with problems of state of mind under rule $10 \mathrm{~b}-5,{ }^{83}$ little clarity exists regarding the existence of an intent or scienter requirement under the rule. Analysis of the state of mind problem can be aided by careful definition. One approach toward definition follows:

1. Deliberate conduct exists when the defendant has an intent to injure others.

2. Knowing conduct exists when the defendant acts with the knowledge that his acts may injure others. Knowing conduct would include knowing misrepresentation or nondisclosure.

3. Reckless conduct exists when the defendant acts in conscious disregard of, or indifference to, the risk that others will be misled. This conduct includes what is sometimes referred to as "gross negligence."

4. Negligent conduct exists when the defendant acts unreasonably but does not act with conscious disregard of consequences.

5. Innocent conduct exists when the defendant cannot reasonably be expected to know the true facts. ${ }^{84}$

The above definitions become important as a means of providing dividing lines in order to determine which conduct is culpable. In securities law fraud cases under rule $10 \mathrm{~b}-5$, the crucial question is whether negligent conduct does or should give rise to liability. According to one commentator, scienter is established when the defendant intends to defraud, has actual knowledge, or has acted in reckless disregard of the truth:

83. For comment regarding the confusion, see Kohn v. American Metal Climax, Inc., 458 F.2d 255, 270, 279-89, 312-16 (3d Cir. 1972) (dissenting opinion of Adams, J.); Bucklo, Scienter and Rule I0b-5, 67 Nw. U.L. Rev. 562 (1972); Ruder, Multiple Defendants, supra note 38, at 631 .

84. These categories are drawn from Ruder, Texas Gulf Silphur-The Second Round, supra note 21, at 435-37, which relies in turn upon W. PROSSER, HANDBOOK OF THE LAW OF TORTs 715-19 (3d ed. 1964). 
To summarize, scienter should be interpreted to mean knowledge of the facts, either actual or constructive. The latter is found when a defendant's lack of knowledge is the result of conduct sufficiently careless that knowledge will be attributcd. Although a court in such a case may not be convinced that the defendant did actually know the facts, his lack of knowledge is inexcusable. Negligence, in contrast, refers to conduct not wholly innocent but not so careless as to be inexcusable. ${ }^{85}$

The confusion in semantics regarding the proper definition of scienter has resulted in great uncertainty between and even within federal circuit courts interpreting rule $10 \mathrm{~b}-5{ }^{86}$ For instance, in two cases decided in 1972, the Seventh Circuit articulated what seem to be inconsistent expressions of the scienter requirement. In Parrent $v$. Midwest Rug Mills, Inc. ${ }^{87}$ the court agreed with the statement in Vanderboom v. Sexton, ${ }^{88}$ an Eighth Circuit case, that scienter is not a necessary element in rule 10b-5 cases. ${ }^{89}$ Subsequently, in Dasho $v$. Susquehanna Corp..$^{90}$ the Seventh Circuit seemed to acknowledge a scienter requirement in rule $10 \mathrm{~b}-5$ actions, stating with regard to certain defendants that "to the extent intent is relevant the evidence is adequate,"91 while with regard to others "there may be some defendants who did not have the requisite state of mind." 92

Basing the dividing line regarding culpability upon the distinction between recklessness and negligence offers the trier of fact the best opportunity to achieve just results. Despite the seeming inconsistency in circuit court language, this dividing line appears to be the uniform standard chosen. After an exhaustive survey of rule $10 \mathrm{~b}-5$ cases, one commentator has stated:

85. Bucklo, supra note 83 , at 570 .

86. For lists of decisions of courts of appeal, see Ruder, Multiple Defendants, supra note 38, at 632 n.154. See also Kohn v. American Metal Climax, Inc., 458 F.2d 255, 286 (3d Cir. 1972) (dissenting opinion of Adams, J.). One commentator has examined the holdings of each circuit in detail. See Bucklo, supra note 83, at 598-600.

87. 455 F.2d 123 (7th Cir. 1972).

88. 422 F.2d 1233, 1238-39 (8th Cir.), cert. denied, 400 U.S. 852 (1970).

89. 455 F.2d at 126. After discussing interpretations of section $10(\mathrm{~b})$ in other circuits, the court in Vanderboom had stated:

This Court has said that '[p]roof of 'scienter,' i.e., knowledge of the falseness of the impression produced by the statements or omissions made, is not required under Section 10(b) of the Act." (citations omitted). 422 F.2d at 1239.

The Parrent court reached its interpretation of the scienter requirement in the course of deciding which state statute of limitations to apply. See notes 102-07, 118-21 infra and accompanying text.

90. 461 F.2d 11 (7th Cir. 1972).

91. Id. at 29 (emphasis added).

92. Id. at 29-30 n.45. 
Examination of all the circuit court decisions discussing the scienter problem reveals that liability has yet to be imposed in a private action for damages where the defendant's conduct was merely negligent; damage awards to private plaintiffs have been confined to cases where either knowing or reckless conduct was the cause of injury..$^{33}$

Obviously, a trier of fact will have enormous leeway in deciding whether conduct was reckless or merely negligent. A finding of recklessness can be made when fairness points to liability, while a finding of mere negligence or "good faith" should serve as a statement that the defendant's conduct did not warrant the imposition of liability under the circumstances of the case.

In choosing a dividing line based upon the defendant's state of mind, it should be noted that concern over finding this line stems primarily from the open-ended liability resulting from dispensing with the privity requirement. When a face-to-face transaction takes place, it makes sense to relax the culpability requirement in order to allow parties who have been persuaded by negligent or innocent misrepresentations to obtain the return of their property or funds. This result is consistent with the common law concept permitting an action for rescission based upon innocent misrepresentation..$^{94}$

The above analysis points to the same conclusion regarding the scienter or intent requirement as that reached with regard to the elements of materiality, reliance and causation. Although the expressed standard being utilized in a given case may differ, the application of that standard will afford the trier of fact an opportunity to achieve fair results under all of the circumstances. Applying these elements in combination affords further flexibility with regard to outcome.

\section{STATUTES OF Limitation}

A fifth area in which the trier of fact may influence result is in applying statutes of limitation. In reviewing limitation statutes the trier of fact must determine whether the plaintiff has brought suit within the specified time period. The trier of fact can influence result either by deciding that the plaintiff has or has not brought suit within the applicable period or by limiting the period for which damages may be assessed.

93. Bucklo, supra note 83 , at 563 (citations omitted).

94. See W. Prosser, Law of Torts 709, 711 (4th ed. 1971). See also the discussion of the relationship of foreseeability and state of mind in non-privity cases in Ruder, Multiple Defendants, supra note 38 , at 612-18. 
A second factual determination which may influence the result is an inquiry regarding the question of whether application of the relevant statute has been delayed or tolled. Although it seems well settled that the "federal tolling doctrine" as expressed in Holmberg $v$. Armbrecht ${ }^{95}$ applies to rule $10 \mathrm{~b}-5$ actions, ${ }^{96}$ the meaning of that tolling doctrine is not clear. The soundest interpretation seems to be that where a person has been injured by fraud, his lack of diligence in pursuing his rights, which normally would bar his claim, will be excused by a defendant's fraudulent concealment. This standard implies further that a plaintiff can assert the tolling doctrine even in the absence of defendant's concealment if the plaintiff was diligent in his efforts to discover the fraud. ${ }^{97}$

Although factual determinations regarding tolling and plaintiff's compliance with the applicable limitation period should provide

95. 327 U.S. 392 (1946). See Bailey v. Glover, 88 U.S. (21 Wall.) 342, 348 (1874).

96. See Azalea Meats, Inc. v. Muscat, 386-F.2d 5, 8 (5th Cir. 1967); Janigan v. Taylor, 344 F.2d 781, 784 (1st Cir.), cert. denied, 382 U.S. 879 (1965). The federal tolling doctrine apparently applies to state limitation periods employed by federal,courts in rule $10 \mathrm{~b}-5$ actions even though the state provision specifically provides that the statute shall not be tolled.

97. This interpretation is derived from the Holmberg case in which the Supreme Court stated:

If want of due diligence by the plaintiff may make it unfair to pursue the defendant, fraudulent conduct on the part of the defendant may have prevented the plaintiff from being diligent and may make it unfair to bar appeal to equity because of mere lapse of time.

Equity will not lend itself to such fraud and historically has relieved from it. It bars a defendant from setting up such a fraudulent defense, as it interposes against other forms of fraud. And so this Court long ago adopted as its own the old chancery rule that where a plaintiff has been injured by fraud and "remains in ignorance of it without any fault or want of diligence or care on his part, the bar of the statute does not begin to run until the fraud is discovered, though there be no special circumstances or efforts on the part of the party committing the fraud to conceal it from the knowledge of the other party. . . ."

This equitable doctrine is read into every federal statute of limitation. If the Federal Farm Loan Act had an explicit statute of limitation for bringing suit under $\S 16$, the time would not have begun to run until after petitioners had discovered or had failed in reasonable diligence to discover the alleged deception by Bache which is the basis of this suit. 327 U.S. at $396-97$ (citations omitted).

See also Schulman, Statutes of Limitation in 10b-5 Actions: Complication Added to Confusion, 13 WAYNE L. REv. 635, 638 (1967) ("if the federal action is denominated fraud, the limitation period commences from the time of plaintiffs diligent discovery of the wrong ...."). An even more liberal interpretation of the Holmberg case appears in Janigan v. Taylor, 344 F.2d 781, 784 (1st Cir.), cert. denied, 382 U.S. 879 (1965) ("Federal law has long been established, with more liberality than that of Massachusetts, that where fraud is involved the cause of action is, so-to-speak, automatically concealed, and does not arise until discovery."). 
means of achieving fairness, results in the limitation area are frequently unfair because the procedure for selecting a limitation period to be applied in rule $10 \mathrm{~b}-5$ actions does not yield uniform results. ${ }^{08}$ The selection of a limitation period, in contrast with the factual determinations discussed above, involves a court decision regarding a question of law. Since Congress did not enact a specific limitation period for section $10(\mathrm{~b})$ actions, federal courts have limited such actions by using forum state limitation periods..$^{99}$ Limitation periods ranging from one to ten years have been applied in section $10(\mathrm{~b})$ actions as a result of differences in the forums selected and differences in court decisions regarding which statute should be used within a particular forum. ${ }^{100}$

Most recently, federal courts have chosen the applicable limitation period by applying a "resemblance test." Basically, the court will first determine what the substantive elements of a rule $10 \mathrm{~b}-5$ action are in that circuit; second, look to law of the forum state to ascertain where that type of action fits into the state statutory scheme; and third, apply the state limitation period that most closely resembles the rule $10 \mathrm{~b}-5$ action. ${ }^{101} \mathrm{~A}$ recent example of this approach appears

98. See III L. Loss, Securities Regulation I774-76 (2d ed. 1961); Schulman, supra note 97, at $641-43$.

99. See, e.g., Parrent v. Midwest Rug Mills, Inc., 455 F.2d 123 (7th Cir. 1972); Sackctt v. Beaman, 399 F.2d 884, 890 (9th Cir. 1968); Janigan v. Taylor, 344 F.2d 781, 783 (Ist Cir.), cert. denied, 382 U.S. 879 (1965). See also Schulman, supra note 97, at 638-42.

The theory that state statutes should provide the source of limitation periods when a fedcral statute is silent on the matter is set forth in UAW v. Hoosier Cardinal Corp., 383 U.S. 696 (1966), where the Supreme Court considered the question of what limitation statute applied to section 301 of the Labor Management Relations Act, 29 U.S.C. $\$ 141$ et seq. (1970). The statute did not contain an overall limitation provision for implied private actions brought under section 301. Rejecting the position that the Court should "devise a uniform time limitation to close the statutory gap left by Congress," the Court concluded that "there is no justification for the drastic sort of judicial legislation that is urged upon us." 383 U.S. at 701-03. The Court held that statc statutes of limitation rather than a judicially created limitation period would govern implied private actions brought under section 301. A similar result has occurred in lower court decisions involving implied private rights of action under section 10(b) of the 1934 Act. The Supreme Court has not ruled on the question. See Schulman, supra note 97, at 638-42.

100. E.g., Denny v. Performance Systems, Inc., [1971-72 Transfer Binder] CCH Fed. SEc. L. REP. I 93,387 (M.D. Tenn. 1971) (Tennessee 10 year general limitation period); Weiscr v. Schwartz, 286 F. Supp. 389 (E.D. La. 1968) (Louisiana one year fraud statute). Each state has several different limitation periods that could be applied to a rule $10 \mathrm{~b}-5$ action. These include limitation periods applicable to fraud actions, periods for contract or tort actions, blue sky periods, and state "catch-all" limitation periods.

101. See, e.g., Parrent v. Midwest Rug Mills, Inc., 455 F.2d 123 (7th Cir. 1972); Mitchell v. Texas Gulf Sulphur Co., 446 F.2d 90 (I0th Cir. 197I); Douglass v. Glenn E. Hinton Inv. Inc., 440 F.2d 912 (9th Cir. 1971); Vanderboom v. Sexton, 422 F.2d 1233 (8th Cir. 1970); Charney v. Thomas, 372 F.2d 97 (6th Cir. 1967). 
in Parrent v. Midwest Rug Mills, Inc. ${ }^{102}$ in which the Seventh Circuit held that the three year limitation period of the Illinois Securities Act of $1953^{103}$ applied to rule $10 \mathrm{~b}-5$ claims. ${ }^{104}$ The court found that the Illinois blue sky law had the same basic purposes as the federal law, contained similar provisions and, except for the interstate elements of rule $10 \mathrm{~b}-5$, covered the same violations. ${ }^{105}$ The court noted that the statute of limitations under the Illinois Securities Law paralleled the express limitation periods in other sections of the 1934 Act. ${ }^{106}$ In declining to apply the Illinois limitation period for actions based on fraud, the court announced the proposition that neither the Illinois nor federal securities law requires a plaintiff to prove scienter on the part of the defendant. ${ }^{107}$

Prior to its Parrent decision the Seventh Circuit had followed other courts in choosing a statute of limitations based upon fraud. ${ }^{108}$ In light of many decisions characterizing rule $10 \mathrm{~b}-5$ as an "antifraud" provision, federal courts usually have applied the limitation period thought to govern fraud actions. ${ }^{109}$ In a 1967 case, Charney $v$.

102. 455 F.2d 123 (7th Cir. 1972).

103. ILL. ANN. STAT. ch. $121 \frac{12}{2}, \S 137.13$ (Smith-Hurd 1960).

104. $455 \mathrm{~F} .2 \mathrm{~d}$ at 127.

105. Id. at 127-28.

106. Id.

107. Id. at 128.

108. Morgan v. Koch, 419 F.2d 993 (7th Cir. I969); Butterman v. Steiner, 343 F.2d 519 (7th Cir. 1965); Northern Trust Co. v. Essaness Theatres Corp., 103 F. Supp. 954 (N.D. Ill. 1952).

109. The following illustrative decisions by courts of appeal have applied state limitation periods other than "blue sky" periods to rule 10b-5 actions:

First Circuit: Janigan v. Taylor, 344 F.2d 781 (1st Cir. 1965), ccrt. denied, 382 U.S. 879 (1965).

Second Circuit: Klein v. Auchincloss, Parker \& Redpath, 436 F.2d 339 (2d Cir. 1972); H.L. Green Co. v. MacMahon, 3I2 F.2d 650 (2d Cir. 1962), cert. denied, 372 U.S. 928 (1963); Fischman v. Raytheon Mfg. Co., 188 F.2d 783 (2d Cir. 1956).

Third Circuit: Tobacco \& Allied Stocks, Inc. v. Transamerica Corp., 244 F.2d 902 (3d Cir. 1957).

Fifth Circuit: Azalea Meats, Inc. v. Muscat, 386 F.2d 5 (5th Cir. 1967); Hooper v. Mountain States Sec. Corp., 282 F.2d 195 (5th Cir. 1960). But see Aboussie v. Aboussie, 441 F.2d 150 (5th Cir. 1971).

Sixth Circuit: Charney v. Thomas, 372 F.2d 97 (6th Cir. 1967).

Ninth Circuit: Douglas v. Glenn E. Hinton Inv., Inc., 440 F.2d 912 (9th Cir. 1971); Sackett v. Beaman, 399 F.2d 884 (9th Cir. 1968); Turner v. Lindquist, 377 F.2d 44 (9th Cir. 1967); Errion v. Connell, 236 F.2d 447 (9th Cir. 1956); Fratt v. Robinson, 203 F.2d 627 (9th Cir. 1953).

Tenth Circuit: Mitchell v. Texas Gulf Sulphur Co., 446 F.2d 90 (I0th Cir.), cert. denied, 404 U.S. 1004 (1971). 
Thomas, ${ }^{110}$ the Sixth Circuit began a new approach by suggesting that the state securities law period should be used in rule $10 \mathrm{~b}-5$ actions rather than the state fraud limitation period. Although the court chose to apply a fraud statute, it did so on the theory that the Michigan blue sky statute did not have a provision resembling rule $10 \mathrm{~b}-5$. The court hinted, however, that it would have applied a blue sky limitation period had one been in existence. ${ }^{111}$

Subsequently, in Vanderboom v. Sexton, ${ }^{112}$ the Eighth Circuit interpreted the Charney decision to mean that the limitation provision must be one that best effectuates the federal policy at issue. Comparing rule $10 \mathrm{~b}-5$ to state common and statutory law, the court affirmed a district court's holding that the defendants' rule $10 \mathrm{~b}-5$ claim was barred by the Arkansas two-year blue sky statute of limitations. ${ }^{113}$

The contrasting results reached in the Sixth and Eighth Circuits can be traced to their differing articulations of the scienter requirement in a rule 10b-5 action. In Charney, the Sixth Circuit characterized a rule $10 \mathrm{~b}-5$ action as analogous to common law fraud, requiring some proof of scienter. ${ }^{114}$ The court concluded that because of the difficult problem of proving scienter, plaintiffs should be allowed the advantage of a longer limitation period in a rule $10 \mathrm{~b}-5$ action. ${ }^{115}$ In Vanderboom, the Eighth Circuit stated that scienter was not a necessary element in rule $10 \mathrm{~b}-5$ actions $^{116}$ and that plaintiffs could recover

The following circuit courts have applied state "blue sky" limitation periods to Rule 10b-5 actions:

Seventh Circuit: Parrent v. Midwest Rug Mills, Inc., 445 F.2d 123 (7th Cir. 1972).

Eighth Circuit: Vanderboom v. Sexton, 422 F.2d 1233 (8th Cir.), cert. denied, 400

U.S. 852 (1970).

There are no reported cases for the Fourth and District of Columbia Circuits.

110. 372 F.2d 97 (6th Cir. 1967).

111. Id. at 100. The Charney court discussed the interpretations of section 10(b) actions by other courts which had concluded that a rule $10 \mathrm{~b}-5$ action was similar to an action for common law fraud. It acknowledged that despite some differences between actions based upon rule 10b-5 and those based upon common law fraud, the applicable statute should be the Michigan fraud statute. With regard to the Michigan blue sky statute, the court stated:

Although in some cases the local Blue Sky Law might be the more appropriate point

of reference, in the present case the Michigan law contains no provisions similar to section $10(\mathrm{~b})$ of the federal law. Id.

112. 422 F.2d 1233 (8th Cir. 1970).

113. Id. at 1237-39, citing A. Bromberg, Securities LAW Fraud-SEC Rule I0b-5 $\$ 2.5(1)$ n. 105 (limitation provisions in state Blue Sky laws, which are aimed at securities fraud, would seem to be an obvious choice in $10 \mathrm{~b}-5$ cases.).

114. 372 F.2d at 99.

115. $I d$.

116. 422 F.2d at 139. See note 89 supra. 
for negligent misrepresentations. ${ }^{17}$

The difficulties caused by determining the applicable state statute of limitations through use of a "resemblance" test are well illustrated not only by the differing results in the Charney and Vanderboom decisions but also by the confusion caused in the Seventh Circuit by the recent Parrent case. In Parrent, the Seventh Circuit's selection of a three year statute was based in part upon absence of a scienter requirement. ${ }^{118}$ At approximately the same time, the Seventh Circuit intimated in Dasho v. Susquehanna Corp. ${ }^{119}$ that a scienter requirement still exists. ${ }^{120}$ These cases have created confusion regarding the existence of a scienter requirement in the Seventh Circuit. They demonstrate an unfortunate judicial tendency to deal in the abstract with the substantive elements of a rule $10 \mathrm{~b}-5$ action. Certainly, the important question of whether proof of scienter is necessary in a rule 10b5 action should not be decided in the context of determining which statute of limitations should be applicable.

The Parrent decision was justified in part on the grounds that application of the Illinois blue sky limitation period would promote greater uniformity -in situations involving a violation of both the federal and Illinois securities laws, a uniform limitation period could be used by the court. ${ }^{121}$ Although the search for uniformity is to be applauded, the Parrent decision achieves uniformity in only limited circumstances.

Uniformity breaks down even within the Seventh Circuit, since the blue sky limitation periods of the states in that circuit vary widely. The Illinois blue sky law provides that an action shall be brought within three years from the time of the wrong, ${ }^{122}$ Indiana requires suit within two years from the date of discovery; ${ }^{123}$ and Wisconsin allows an action to be brought within one year of discovery but not later than three years from the time of the wrong. ${ }^{124}$ Application of the resemblance test developed in the Parrent decision thus could result in the application of any one of three different limitation periods, depending on which state is treated as the forum state. The lack of uniformity

117. Id.

118. See note 107 supra and accompanying text.

119. 461 F.2d 11 (7th Cir. 1972).

120. Id. at 30. See notes 90-92 supra and accompanying text.

121. 455 F.2d at 127. See also Richardson v. Salinas, 336 F. Supp. 997 (N.D. Tex. 1972).

122. Ill. ANN. STAT. ch. 121 1/2, $₹ 137.13 \mathrm{D}$ (Smith-Hurd 1960).

123. IND. ANN. STAT. $\$ 25-873$ (2)(e) (1970).

124. Wis. Stat. ANN. $§ 551.59$ (5) (1972). 
within circuits further complicates the lack of uniformity between circuits referred to earlier. ${ }^{125}$ Other complications arise when differing limitation periods may be applicable. In addition to deciding which of several statutes within a single state should be applied, a federal court must resolve conflicts of laws problems in choosing which state's laws govern the choice of the limitation statute. It sometimes must ask the difficult question, "Where did the cause of action arise?"126 Moreover, as part of its conflicts of laws decision, a court may be faced with problems caused by borrowing statutes, which, in general, provide that if the action has been barred by the limitation statute of the jurisdiction in which the cause of action originated, suit in another forum will not result in the application of the longer limitation period of that forum. ${ }^{127}$

The best solution to the limitation question would be to look to federal rather than state law for a limitation period. The federal securities laws provide a ready source from which to choose a limitation period. When dealing with express liability provisions of the federal securities acts, Congress adopted relatively uniform limitation provisions. A one and three year limitation period is contained in section 13 of the 1933 Act $^{128}$ and sections 9(e), 18(c), and 29(b) of the 1934 Act. ${ }^{129}$ Section 9(e) is typical:

No action shall be maintained to enforce any liability created under this section, unless brought within one year after the discovery of the faets constituting the violation and within three years after such violation..$^{130}$

125. See note 100 supra and accompanying text.

126. See Saylor v. Lindsley, 302 F. Supp. 1174, 1179-82 (S.D.N.Y. 1969), rev'd on other grounds, 456 F.2d 896 (2d Cir. 1972).

127. See Trussel v. United Underwriters, Ltd., 236 F. Supp. 801 (D. Colo. 1964). On a motion to dismiss one defendant raised the issue of whether the Colorado or Kansas limitation provisions should apply. The court held that it was bound to apply the law of the forum state with respect to the applicable limitation period, "and that this may require the adoption of the forum state's "borrowing statute," 236 F. Supp. at 803, citing Cope v. Anderson, 33! U.S. 461 (1946). The Colorado borrowing statute applied by the court provides:

When a cause of action arises in another state or territory or in a foreign.country, and by the laws thereof an action thereon cannot be maintained against a person by reason of the lapse of time, an action thereon shall not be maintained against him in this state. Colo. Rev. StaT. ANN. \& 87-1-19 (1963).

While the district court applied the Kansas two year limitation provision, it did not dismiss the plaintiff's claim because the federal tolling doctrine applied irrespective of the applicable limitation provision. $236 \mathrm{~F}$. Supp. at 803.

128. 15 U.S.C. $\$ 77 \mathrm{~m}(1970)$.

129. Id. $\S 78 \mathrm{i}(\mathrm{e}), \mathrm{r}(\mathrm{c}), \mathrm{cc}(\mathrm{b})$.

130. Id. $\S 78 i(\mathrm{e})$. Section $18(\mathrm{c})$ of the $1934 \mathrm{Act}$, id. $78 \mathrm{r}(\mathrm{c})$, expressly provides for a one and three year limitation period for misleading statements. In addition, section $29(\mathrm{~b}), i d . \S 78 \mathrm{cc}(\mathrm{b})$, 
These limitation periods represent a Congressional viewpoint fixing limitation periods for actions based upon violation of the securities laws which could easily be followed by federal courts.

Choice of the federal limitation period not only would create uniformity but would correct what must be judged as a mistake in application of principle. Historically, the application of state statutes of limitation to federally created rights of action have developed because express federal limitation periods have not been available. ${ }^{131}$ The rationale for applying state statutes of limitation to federal securities law actions originated in a non-securities law case, Campbell $v$. Haverhill, ${ }^{132}$ in which the plaintiffs brought a patent infringement suit based on a federal statute which had no limitation period. The defendant argued that the claim was barred by a Massachusetts six year limitation period. Rejecting plaintiff's argument that the laws of the states have no application to causes of action "created by Congressional legislation and enforceable only in the Federal courts," the Court held the state limitation period applied. The Court supported its decision by suggesting that Congress surely would not have intended that the underlying right would exist with no time limitation whatsoever. It stated:

In creating a new right and providing a court for the enforcement of such right, must we not assume that Congress intended that the remedy should be enforced in the manner common to like actions within the same jurisdiction?

Unless this be the law, we have the anomaly of a distinct class of actions subject to no limitation whatever; a class of privileged plaintiffs who, in this particular, are outside the pale of the law, and subject to no limitation of time in which they may institute their actions. ${ }^{134}$

The assumption after Haverhill that no federal statute could exist

contains a special one and three year provision applicable to contracts void under sections $15(\mathrm{c})(2)$ and (3), id. $\$ 78 o(\mathrm{c})(2),(3)$. Section $16(\mathrm{~b})$, id. $\$ 78 \mathrm{p}(\mathrm{b})$, contains a two year limitation period. Section 13 of the 1933 Act, $i d$. $\$ 77 \mathrm{~m}$, contains a similar one and three year limitation period applicable to sections $11,12(1),(2), i d$. $\$ 77 \mathrm{k}, l(1),(2)$. Originally, the 1933 Act provided for a two year limitation period from the date of discovery of the fraudulent misrepresentations and an overall ten year limitation period for all actions except those under section 12(2). Act of May 27, 1933, ch. 38, § 13, 48 Stat. 84. In 1934 the Act was amended to provide for the one and three year period in section 13. Act of June 6, 1934, ch. 404, § 207, 48 Stat. 908. See Schulman, supra note 97, at 637.

131. See Chevron Oil Co. v. Huson, 404 U.S. 97 (1971); UAW v. Hoosier Cardinal Corp., 383 U.S. 696 (1966); McAllister v. Magnolia Petroleum Co., 357 U.S. 22 I (1958); Schulman, supra note 97 , at 638-39.

132. 155 U.S. 610 (1895).

133. Id. at 614 .

134. Id. at 616. 
by implication seems unjustified. ${ }^{135}$ As noted by several Supreme Court justices, statutes of limitation contained in similar federal laws may provide ready and logical sources from which to draw limitation provisions by implication. ${ }^{136}$ In federal securities law litigation, the choice is not between a state statute and none at all, but between an analogous federal limitation period and a multitude of state statutes. ${ }^{137}$

Several leading commentators have concluded that reference to federal securities laws is the most logical solution to the limitation problem. ${ }^{138}$ Professor Loss has suggested that federal courts now faced with choosing between various state statutes should look instead to an analogous federal statute for a limitation period:

When such a statute does exist-vide $\S 13$-is it not eminently more consistent with the overall statutory scheme to look to what Congress itself did when it was thinking specifically of private actions in securities cases rather than to a grab-bag of more or less analogous state statutes. ${ }^{139}$

135. See McAllister v. Magnolia Petroleum Co., 357 U.S. 221, 227 (1958) (Brennan, J., concurring). In that case the court rejected a lower court decision applying a two year Texas limitation period to an action for negligence under the Jones Act, 46 U.S.C. $\$ 688$ (1970). The Court held that the limitation period applicable to the federal act could not be less than three years. Concurring, Justice Brennan said:

. . . I do not believe that the absence of specific directions from Congress leads nccessarily to the result that state statutes of limitations should apply in cases of this sort. The reason is that the considerations which in Campbell v. Haverhill . . . and Cope v. Anderson . . prompted resort to the state statutes do not apply at all here. Those cases represented intensely practical solutions to a practical problem in the administration of justice. In the absence of any comparable federal statute of limitations which might be applied, the Court had four choices: (1) No period of limitations at all; (2) an arbitrary period applicable in all like cases; (3) the flexible but uncertain doctrine of laches; and (4) state statutes of limitations. The state statutes were chosen by default. 357 U.S. at 228-29 (emphasis added).

Justice Brennan argued that the three year limitation period of the Jones Act was the logical source from which to draw an analogous limitation provision. Id. at 229. See also UAW v. Hoosier Cardinal Corp., 383 U.S. 696, 709 (1966) (White, J., dissenting).

136. See notes 128-35 supra and cases cited therein.

137. See UAW v. Hoosier Cardinal Corp., 383 U.S. 696, 709-14 (1966) (White, J., dissenting).

138. See VI L. Loss, Securities Regulation 3899 (1969 Supp.) (citing Schulman, supra note 97). See also Israels, Book Review, 77 YALE L.J. 1585, 1591 (1968) (concurring with a similar conclusion reached by Professor Bromberg. See 2 A. Bromberg, Securities Law Fraud: SEC Rule 10b-S 284). Professor Loss, Reporter for the American Law Institute on the proposed Federal Securities Code, has recently stated that the limitation problem concerning section $10(\mathrm{~b})$ and rule $10 \mathrm{~b}-5$ is one that is in "crying need" of rationalization. Professor Loss ends his discussion of the limitation "anomaly" with the question-"Why should there be a longer period for implied rights of action than for express? I'm not suggesting that we 


\section{CONCLUSION}

In attempting to analyze ways in which factual determinations may influence results in rule $10 \mathrm{~b}-5$ cases, this article has referred to five areas: materiality, reliance, causation, scienter, and statutes of limitation. The basic proposition asserted is that fair results will be reached if the trier of fact has many areas of flexibility in which to make decisions favorable to the person or persons it deems to have the greatest equities. As a corollary to the basic proposition, the discussion of each area has carried with it the following suggestions for shaping legal theory in ways so that flexibility will be preserved for the trier of fact.

1. Materiality. The flexible definition of materiality should be preserved.

2. Reliance. In litigation arising from face-to-face transactions, the plaintiff should meet the burden of proving reliance. In impersonal class actions resulting from market transactions, proof of reliance can be presumed, but the defendant should be entitled to offer proof negating the presumption either as to the class or as to an individual member of the class.

3. Causation. Factual inquiry regarding cause in fact should center upon the question whether defendant's conduct was a substantial factor in plaintiff's loss. The concept of legal cause should be recognized and treated as involving policy determinations.

4. Scienter. In most cases the line distinguishing liability from non-liability should be whether the defendant's conduct was deliber-ate, knowing, or reckless. In cases arising from face-to-face transactions, however, the common law concepts of rescission based upon negligent or even innocent conduct should be maintained.

5. Statutes of limitation. A uniform federal statute of limitations should replace the present system of searching for the applicable state statute. In any event, cases involving statutes of limitation are inappropriate vehicles for determining policy issues regarding scienter and other elements of rule $10 \mathrm{~b}-5$ cases.

These comments reflect the general and broad language of rule $10 \mathrm{~b}-5$, the ad hoc nature of developments under the rule, the trend

should shorten the one-perhaps we should lengthen the other-but there is an anomaly there." ALI FED. SEC. CoDE xxxvii-viii (Tentative Draft No. 2, April 25, 1972) (approved in part May, 1972).

139. VI L. Loss, supra note I38. 
toward flexible interpretation of the securities laws, and the existence of implied private rights of action based upon the need to provide remedies for conduct declared unlawful by the Congress and the Securities and Exchange Commission. Until Congress and the SEC move to create a more orderly system, the responsibility for achieving orderly development lies with the courts. Hopefully, future court decisions will be guided by the need to provide careful guidelines under which limitations on rule 10b-5 liability will reflect considerations of fairness. 